\title{
LITERARY TRANSLATION AS PERFORMANCE. THEORETICAL QUESTIONS AND A LITERARY ANALOGY
}

\author{
Angela Locatelli* \\ University of Bergamo
}

The aim of this essay is to propose a view of literary translation as "performance", i.e., as both an art and an activity endowed with specific affinities with those of the actor or the musician. Actors and musicians offer subjective interpretations of the dramatic texts and of the musical scripts that they present on stage and in the concert hall. Likewise, the translator presents her/his interpretation and her/his rendering of a specific text to readers whose mother tongue and culture may either be close or remote from the ones of the original. In other words, a translator of artistic literature is 'a performer' and each translation an 'execution' i.e., a unique 'rendering of the script' (T1), and it is both a recognizable prior text (T1) and yet also a specific variation of it (T2). After some theoretical observations on translation (Part 1 of the essay), my thesis will be developed in connection with an interpretation of the character of Bottom, the weaver-actor in A Midsummer Night's Dream, because his experience and 'personality', seem to bear interesting metaphorical affinities with those of the translator as performer of poetic texts (Part 2 of the essay).

Keywords: translation, performance, aesthetic enjoyment, theory and poetics of translation, literature, Shakespeare.

\section{Introduction}

Several valuable approaches to translation have been proposed for centuries (one may think of Biblical translations as compelling examples). More recently, the focus has been on new theoretical definitions and methods. Starting from the findings of recent studies on translation, this article wishes to contribute to the issue by suggesting an idea of "translation as

*angela.locatelli@unibg.it

This work is licensed under a Creative Commons Attribution-NonCommercial 4.0 International License.
Received: 01.02.2021

Revised: 10.04 .2021

Accepted: 20.05.2021

(C) The Author(s) 2021 
performance". In other words, the translator, like the artist or musician is here perceived as one who offers a specific "execution" of the prior text, a unique rendering of T1, which is based on the translator's purposes towards the imagined recipients, as well as on her/his specific linguistic and cultural competence. The psychological and methodological attitudes of the translator clearly have a strong impact on the result of her/his work. The complex position of the translator are here explored and discussed in relation to those of a well-known literary figure, Bottom, because this Shakespearean character embodies the multifaceted desires and abilities of a lively "performer".

\section{Some theoretical remarks on translation as performance}

Our experience of the enjoyment of music demonstrates that we receive and appreciate a symphony or a concerto (for example Vivaldi's or Chopin's) in the specific rendering that an artist-musician offers us. For instance, we can relish Vivaldi's Four Seasons played either by Victoria Mullova or by Giuliano Carmignola, and we are moved by Chopin Nocturnes played either by Maurizio Pollini or by Vladimir Ashkenazy. In these cases, our reception, and concomitant aesthetic emotions, are rooted in a double recognition: the recognition of the musical piece (for example, The Four Seasons or The Nocturnes) and simultaneously another recognition concerning the performer's specific rendering (Mullova or Carmignola's, Pollini or Ashkenazy's execution).

Something similar happens in our enjoyment of plays when we already know the script, or of plays which we have already seen in different performances. Our aesthetic pleasure is bound to the double perception of the script and the director's and actors' joint rendering of it. The double recognition we experience in music and in the theatre is similar to our enjoyment of translation(s) as a specific performance of the original script.

The performance of the translator concerns both the activity of translating and the result of such endeavor. The former includes the hermeneutic activity that precedes and accompanies any act of translation (Schleiermacher, 1838/1998; Mueller-Vollmer, 1989; Gasparyan, 2018; Thiselton, 2019), and the translator's execution of the text includes also the numerous questions at philosophical (Derrida 1985, 2012; Hermans, 1985; 
Graham, 1985), linguistic, and technical level, which the translator, and especially the good translator, must ask and answer while completing her/his task. The result always elicits a double response in readers who are familiar with $\mathrm{T} 1$ (the script); in this sense a satisfactory translation resembles a good performance.

The translator as performer means that the reader of the original, who knows both the language of departure (of T1) and of arrival (of T2), can evaluate and appreciate the strategies and stylistic choices made by the translator, which remain her/his choice and responsibility. The translator has therefore to be accountable to herself/himself and to be the judge (albeit certainly not the only one) of her/his work. Readers are also entitled to evaluate a translation according to their own parameters, which are indebted to cultural norms, to moral and aesthetic values, as well as to individual tastes. Such appraisals will necessarily be both subjective and time and culture specific.

No two translations of the same text will ever be the same, because the art of the translator is genuinely creative, and we can legitimately talk of a "poetics" of translation, as well as of "theories" (Pym, 2014; van Doorslaer, 2013; Bachmann-Medick, 2013; Peeters, 2005; Frawley, 1984), and "methods" (Flynn \& Gambier, 2011; Larson, 1984) of translation.

Different texts call for different translation strategies and a basic distinction between technical and scientific texts versus poetic texts and artistic narratives must set the agenda towards a basic approach to the translation (Delabatista, 2011; Hermans, 1985; Frawley, 1984). While technical and scientific texts should prioritize information and provide a univocal and unequivocal meaning (for example, I need clear details in order to understand how to run machinery or sail a boat), literary translations should remain open to the polysemy of the original and to its semantic complexity (Locatelli, 2009), intertextual allusions, and poetical suggestiveness.

If we are speaking of translation in a strict sense, the priority of the original text seems out of the question; however, this does not mean that such priority amounts to a literal rendering. Given the often incommensurable philosophical, semiotic, grammatical and lexical 
dimensions between the two languages involved, literal translations are impossible, and usually far from satisfactory.

The translator's freedom in $\mathrm{T} 2$ is intrinsic to her/his rendering of $\mathrm{T} 1$ (i.e., to her/his performance, in the above sense) and must be defended as an expression of her/his style. A translation is always an individual response to a text, and to the challenge that it poses for whoever wishes to make it accessible to others. I propose therefore to differentiate between "translations", "adaptations", "re-writings", "transformations" of T1. All of them are legitimate and should be evaluated in their own terms, but the use of T1 is widely different in each of them. In "adaptations", "re-writings", "transformations" T1 becomes the mere "material" for a new aesthetic object, while in "translations" proper T1 is respected, as far as possible, given the incommensurability of the two languages involved. Respect in translation is a necessary virtue: it grows out of a keen and informed attention to the structures of the original, and to a dialogical, rather than predatory attitude towards the work of the author of T1. When dialogue and respect are activated we have the premises for a successful translation.

In fact, I believe that a good translation is one which affords the interpretative richness and complexity of the artistic source text (T1). A translation is most satisfactory and pleasurable when it provokes as many (or nearly as many) interpretations as the ones which the original evokes in readers of $\mathrm{T} 1$ in any given place and time. A full and precise rendering of the translated text will never be absolute or definitive, but any rendering will be an approximation by degrees that reaches out towards the (shifting) hermeneutic potential of $\mathrm{T} 1$. In fact, new horizons of meaning are disclosed in history on the same literary text (this is why interpreting the classics is an interminable activity). Since new meanings emerge in different cultural and geopolitical contexts, it follows that translations need to change, with the variations in interpretation that T1 incessantly undergoes (Locatelli, 2021, in press).

\section{Bottom's experience and the translator's performance}

My approach to exploring the nature of translation as performance will, from now on, be supported by my interpretation of an intriguing character in 
A Midsummer Night's Dream, i.e. Nick Bottom, the weaver-actor of the comedy's play-within-the play.

Why do I turn to a Shakespeare play, a literary text par excellence, to probe into the issue of translation, from an unusual, and hopefully innovative perspective? Because I have chosen to let literature itself tell us what the art of translation is about. Andrew Chesterman and Emma Wagner's seminal question: "Can theory help translators?" (2002) must be answered in the affirmative, and also bearing in mind that literature itself provides important metalinguistic clues to sensitive and careful translators. In other words, literature can enhance the progress of theory. I am aware of the fact that this critical proposal may seem adventurous, if not a hazard, to some theorists of translation, but I believe that this is a gesture of legitimate and genuine transdisciplinarity, moving across fields that have been kept apart, but that have an interesting potential in cross fertilization.

Moreover, as philosophers Gilles Deleuze \& Felix Guattari (1975) have convincingly explained, the true poet inhabits her/his own language as a foreigner. In this sense I believe that artistic literature is always already a "translation", it is a "difference" within language itself. No one like the poet can exploit the potential of the language s/he uses, whether s/he is aware of this fact or not. Like poets, the best translators have a rich, serious and complex relationship with at least both languages involved in what they deal with.

In my opinion Bottom's diverse experiences, as well as his lively and shrewd personality and attitude represent quite convincingly, if somehow surprisingly, the art and technique of the translator. This protean character provides precious clues, suggestions, prescriptions and proscriptions on the nature and task of the translator's work as performance.

As we know, Bottom is one of the Athenian "mechanicals" chosen to perform a play in honor of Theseus, the Duke, on the occasion of his wedding with Hippolyta, Queen of the Amazons. The "director" of the play is Peter Quince, a carpenter, who has the difficult task of harnessing the five commoners into their respective acting roles. Together with Bottom, the company is made up of a rather odd assortment of artisans: Francis Flute, a bellows-mender, Tom Snout, a tinker, Snug, a joiner, Robin Starveling, a tailor. 
The first time we meet Bottom is in Act I. Scene 2, when Quince is assigning their respective roles to each of them. Bottom is curious and inquisitive: First, good Peter Quince, say what the play treats on, then read the names of the actors: and so grow to a point (II.i.8-10 emphasis mine). The translator should likewise be inquisitive about the general topic of T1 and, once he has acquired a sufficient competence on the subject, s/he must focus on other elements, such as: the tone of the text s/he is translating, its intertextual dimensions, style, genre conventions, and linguistic stratifications. From this knowledge s/he should figure out what tools (theoretical and methodological) can assist her/him in his planned goal, and last, but not least, s/he should have a clear mind about her/ his purpose (i.e. grow to a point, as Bottom suggests).

Moreover, a good translator, like Bottom who is very concerned on how the Ladies will receive the performance (he is worried that the lion might scare them), has an audience in mind (and s/he has a point to make with her/his readers). The aims and purposes of the translator are her/his own choice entirely, they are her/his responsibility, and from this very start is the translator's work a genuinely creative performance, like the actor's or the musician's. Some translations aim at an almost exclusive and immediate use for the stage, others aim at erudite readers, others to a general public. The virtual readers are often contemporaries of the translator. This explains why translations have a specific duration in time that is relative to both the cultural and historical contexts of their making and to the conditions of their reception. If most $18^{\text {th }}$ and $19^{\text {th }}$ century translations of the classics (I am thinking, for example, of the Italian translations of Shakespeare, see Locatelli, 1999) have an unmistakable elegant taste, but are no longer enjoyable today, this is due to the fact that, as stated above, literature and poetics are in a permanent state of transformation.

Moreover, the purpose(s), i.e. what Bottom calls the point of translation may be highly different: i.e. information, amusement, cultural mediation, updating previous (but by now obsolete) translations, or even adaptation or re-writing of $\mathrm{T} 1$.

Another important aspect of Bottom's affinity with the translator is the fact that he wishes to play nearly all the roles of the interlude. He is not satisfied with performing the leading role of Pyramus, and even in this role he wishes to act a double dramatis persona: both the "lover" and the 
"tyrant". When Flute is assigned the role of Thisbe and is unhappy with it (because he says: I have a beard coming), Bottom immediately proposes to act it himself: An I may hide my face, let me play Thisbe, too. I'll speak in a monstrous little voice: Thisne, Thisne! (I.ii. 47-48). But this is not the last of Bottom's ambitions: in fact, he also wants to play "the lion" (a task assigned to Snug, the joiner): Bottom: Let me play the lion too. I will roar that I will do any man's heart good to hear me... (I.ii.66-67). Bottom is reminded that the lion may frighten "the ladies", but his determination is such that he promises: I grant you, friends, if you should fright the ladies out of their wits they would have no more discretion but to hang us, but I will aggravate my voice so that I will roar you as gently as any sucking dove. I will roar you an 'twere any nightingale (I.ii.74-78). Bottom's determination and the eagerness to adapt he displays in his comical malapropisms underline the fact that he is ready to take his voice across a spectrum from roaring lion to gentle sucking dove and even melodious nightingale.

Bottom's omnivorous appetite and his vocal flexibility takes me to the translator's imperative to "hear" and then perform the widely different voices that are present in any literary text. T1 cannot be rendered in a single tone, a single stimmung, a homogeneous style, or T2 would be unbearably flat. The translator has to respect the polyphony of $\mathrm{T} 1$ and therefore impersonate different voices in $\mathrm{T} 2$, otherwise s/he would efface the many nuances that are proper to each character's speech, to linguistic registers, rhetorical orchestration, authorial voice, etc. A homogeneus tone, in fact, makes some $19^{\text {th }}$ century translations of Shakespeare into Italian (Michele Leoni, Carcano, Giunio Bazzoni-Giacomo Sormani and Andrea Maffei) quite unpalatable today since their high, gentrified, but uniform poetic register, makes T2 too tedious (Locatelli, 1988). As far as I have seen this holds true for similar translations in other languages (which I cannot obviously exemplify in this essay). A translator, in other words, is an impersonator of many voices, while her/his own voice remains manifest in her/his unique style, i.e. in her/his unique execution of T1. Just like Bottom, the waver, the translator is a weaver of texts, his cognitive, erudite and technical knowledge makes her/him the provider of textual artefacts that have a precise and beautiful design. 
Bottom's experiences have a few more features that recall the work of the translator. In Act III scene1 he asks Quince to Write me a prologue in order to explain to the audience that Pyramus dies not in earnest, but in jest. This concern and precaution on the part of Shakespeare's Weaver parallels a similar solicitude in translators who add footnotes to their T2, either to explain cultural elements in $\mathrm{T} 1$ that readers of $\mathrm{T} 2$ are not familiar with, or to highlight philological issues, but also to illustrate the translator's own dilemmas as to the best rendering of a line, a word, an utterance.

Bottom's famous erotic dream suggests one more analogous experience in the art of translation: the dream concerns the doting of the Queen of the Fairies, Titania, who despite the fact that Bottom is wearing an ass head falls in love with his song: I pray thee, gentle mortal, sing again./ My ear is much enamoured of thy note; /so is myne eye enthralled to thy shape;/ And thy fair virtue's force perforce doth move me/On the first view to say, to swear, ! love thee (III.ii.130-134). The same attitude is expressed in IV.i., where Titania, after calling Bottom my gentle joy, exclaims: $O$ how I love thee, how I dote on thee! (IV.i.44). This scene of seduction allows a metaphorical understanding of the translator's encounter with $\mathrm{T} 1$ as a coup de foudre, where $\mathrm{T} 1$ is perceived as irresistible, a text that calls for a further and wider dissemination, so that that others may be in turn seduced by its qualities, beauty and charm. The translator can be seen as both a passive and an active subject of seduction, once seduced, a seducer; this seems plausible since many translators have admitted selecting for translation the texts they most "love". The aim of the translator who deals with his favorite texts is to pay homage to both the text and the author that have seduced him, and then to extend such an experience to her/his readers. The charm of the original for the translator sets the conditions for a dialogue with the prior poet (rather than an abuse of power over her/him). Such dialogue is of course possible if the translator is a good reader/listener, one who "lends an ear" to the notes and echoes of T1. The translator's relationship to his "favorite texts" and the concomitant decision to perform them in translation is, as I have said, one of her/his responsibilities.

Let me now focus on what Bottom describes as the central feature of his famous dream. He says: It shall be called 'Bottom's Dream', because it hath no bottom (IV.i.212-213 (emphasis mine). This is obviously a Shakespearian pun on the protagonist's name, but it says more than just this. 
A Bottom-less dream is a dream without Bottom, which may allude to the "impersonality" of the translator, or better to her/his respect of the original text rather than an intrusive and narcissistic manipulation of it. We are often put off by translators who foreground their own voice at the expenses of the voices in T1. Likewise, we do not condone the arrogance of those who even claim to "improve" the original text. However, this does not mean that the translator is, or should be "absent" or "invisible". Quite the contrary: s/he leaves her/his fingerprints on the translation, because her/his work is always a unique performance. This is why we can talk of a "style" and a "poetics" of translation.

Moreover, the image of a "bottomless" dream speaks of the work of the translator as interminable, in more than one sense. Bottom's vision is, in turn, "translated" into a ballad by Quince, the Director of the play-within the play, and one may surmise that there will be many subsequent versions of it. As I have argued, translations are not everlasting: they must be done again and again in time, but "interminable" also means that there will always be something "left out" and unexpressed even in the best translation, which, like the best poetry, invokes endless further investigation and expression, and opens the path towards other performances.

When Bottom returns to the everyday world out of the "wood", 1 and to the company of the "mechanicals", his fellow artisans-actors say that Bottom is "changed", "transported" and "translated" (Bless thee, Bottom, Bless thee. Thou art translated (III.ii.113 emphasis mine). This is no doubt the effect of the "most rare vision" he had. In this sense, Bottom offers one more metaphorical image of the translator of poetic texts. The translator is, in turn, "translated" by her/his activity, which means that her/his experience of the two worlds that are intrinsic to the two languages he comes to terms with changes his relationship with both languages, and hence with his own way of being in the world. Like Bottom (who inhabits Athens, but also the wood, daylight rationality but also a dream), translators inhabit, in a philosophical and experiential sense, in two or more worlds relative to the languages and texts they deal with. 


\section{Conclusion}

Instead of proposing a "method" of translation in the commonsensical acceptation, I wished to address the possibility of viewing translation "as a performance", and to show that some theoretical premises and some practical and psychological attitudes are always necessary to the translator's successful activity. In fact, like Bottom the actor, the translator "performs" his work best when s/he is inquisitive, has a purpose, has an audience in mind, is able to render the polyphony of the original by impersonating the many voices in $\mathrm{T} 1$. The style of his rendering is unique and recognizable, even if his presence is discreet, like that of an actor who does not foreground her/himself by effacing the dramatic persona s/he is performing. Moreover, the translator's work is interminable ("bottomless"), and s/he shares, with(in) literature and language(s), Bottom's fantastic experience of seduction and change, i.e., he is, like Shakespeare's weaver, "translated".

\section{Notes}

1 Wood is a term that connotes a locus of madness in early-modern English.

\section{References}

Bachmann-Medick, D. (2013). Translational turn. Handbook of Translation Studies, Vol. 4, 186-193. Amsterdam: John Benjamins Publishing Company.

Chesterman, A., \& Wagner, E. (2002). Can theory help translators? A dialogue between the ivory tower and the wordface. London and New York: Routledge.

Delabastita, D. (2011). Literary translation. Handbook of Translation Studies, Vol. 2, 69-78. Amsterdam: John Benjamins Publishing Company.

Deleuze, G., \& Guattari, F. (1975). Kafka. Pour une littérature mineure. Paris: Minuit.

Derrida, J. (1985). The Ear of the other: Otobiography, transference, translation. New York: Schocken Books. 
Derrida, J. (2012). What is a 'Relevant Translation'? The translation studies reader, 365-388. London and New York: Routledge.

Flynn, P., \& Gambier, Y. (2011). Methodology in translation studies. Handbook of Translation Studies, Vol. 2, 88-96. Amsterdam: John Benjamins Publishing Company.

Frawley, W. (1984). Translation: Literary, linguistic and philosophical perspectives. Newark: University of Delaware Press.

Gasparyan, S. (2018). Concerning the program of understanding a literary text. Armenian Folia Anglistika, 18 (1-2), 7-18.

Graham, J. F. (1985). Difference in translation. Ithaca and London: Cornell University Press.

Hermans, T. (1985). The manipulation of literature: Studies in translation. New York: St.Martin's Press.

Larson, M. L. (1984) Meaning-based translation. Lanham (MD): University Press of America.

Locatelli, A. (1988). Traduzioni ottocentesche dell'Othello in Italia: La problematica del contesto. In E. Glass, F.Marroni, G. Micks, \& C. Pagetti (Eds.). Metamorfosi: Traduzione/Tradizione (pp. 293-303), Pescara: Clua.

Locatelli, A. (1999). Shakespeare in Italian romanticism: Literary querelles, translations, and interpretations. In H. Klein and M. Marrapodi (Eds.). Shakespeare and Italy. Shakespeare Yearbook, Volume X (19-37). Lewiston (NY): The Edwin Mellen Press.

Locatelli, A. (2009). The ethical use(s) of literary complexity. In S. Baumbach, H. Grabes \& A. Nünning, (Eds.). Values in literature and the value of literature: Literature as a medium for representing, disseminating and constructing norms and values (pp. 67-76). Trier: Wissenschaftlicher Verlag Trier.

Locatelli, L. (2021). Translation as a catalyst of re-writing and translation as a kind of writing. In F. Scotto (Ed.). Traduzioni esemplari e saggi storici sul tradurre dal Romanticismo a oggi. Milano: Cisalpino Istituto Editoriale Universitario. (in press).

Mueller-Vollmer, K. (1989). The hermeneutics reader. New York: Continuum. 
Peeters, J. (2005). On the relationships between translation theory and translationp. Frankfurt am Main and Berlin: Peter Lang.

Pym, A. (2014). Exploring translation theories. London and New York: Routledge.

Schleiermacher, F.D.E. (1998). Schleiermacher: Hermeneutics and criticism. Cambridge: Cambridge University Press.

Shakespeare, W. (1988). A Midsummer Night's Dream. In S. Wells \& G. Taylor (Eds.). The Oxford Shakespeare. The complete works, 311-333. Oxford: Clarendon Press.

Thiselton, A. C. (2019). On hermeneutics. London and New York: Routledge.

van Doorslaer, L. (2013). Impact of translation theory. In Y. Gambier \& L. van Doorslaer (Eds.). Handbook of Translation Studies, Vol. 4, 77-83. Amsterdam: John Benjamins Publishing Company.

\section{RUपUน PURqUUนกमค्3กhนC กГTEU «UEГGU3U.3กhU»}

\section{Uiqgtilu Lnluuuntıh}

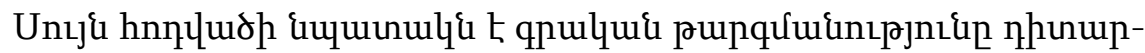

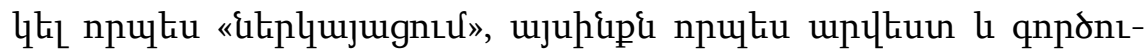

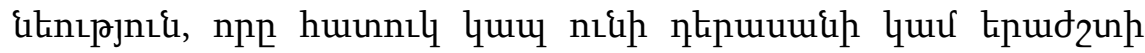

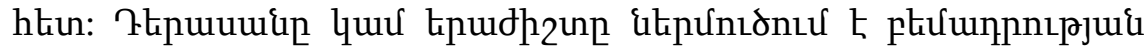

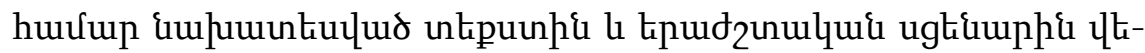

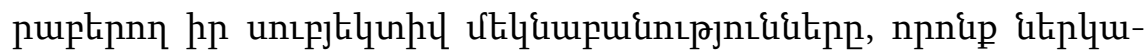

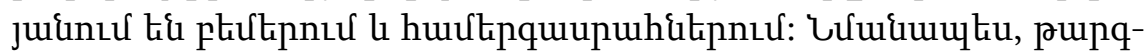

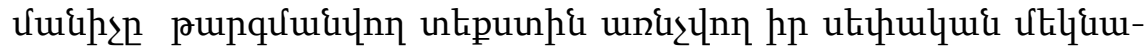

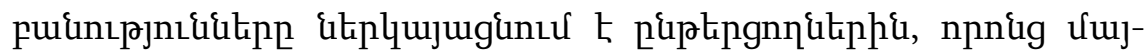

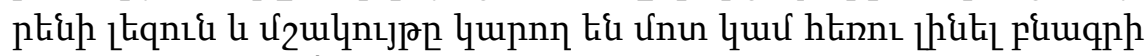

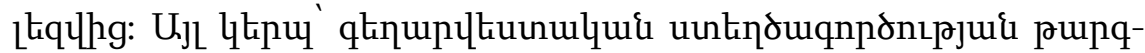

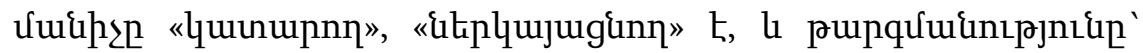

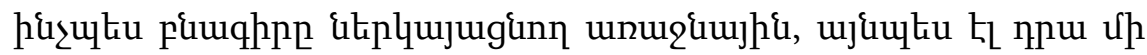
Łplnnpnujh\{ «lquunupnıu» $\mathrm{k}:$

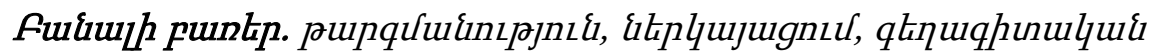

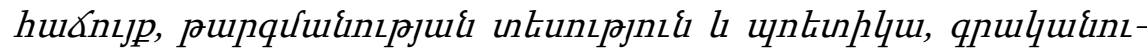
pjnık, Clipuuhp: 